\title{
Risk assessment of toxic Cyanobacteria in Polish water bodies
}

\author{
J. Mankiewicz-Boczek ${ }^{1}$, K. Izyorczyk ${ }^{1} \&$ T. Jurczak $^{2}$ \\ ${ }^{I}$ International Centre for Ecology, Polish Academy of Sciences, \\ Łódź, Poland \\ ${ }^{2}$ Department of Applied Ecology, University of Łódź, Poland
}

\begin{abstract}
Cyanobacteria and cyanotoxins constitute a serious problem for water supply systems and recreation. The most common in Polish water bodies are microcystin-producing Cyanobacteria. Polish regulations regarding the quality of drinking water indicate the limit of $1 \mu \mathrm{g} / \mathrm{l}$ for microcystin-LR. Regulations for recreational water are addressed through a guideline that the water should only be inspected visually. Poland's regulations, unfortunately, do not recommend any specific standardized methods, equipment or programmes for the risk assessment resulting from Cyanobacteria exposure. Therefore, this study is aimed at developing and evaluating a toxicity monitoring programme that would be based on the early identification of microcystin-producing genera, followed by examination of their toxic potential and toxicity. The risk of cyanobacterial blooms was assessed in six eutrophic water bodies located in different regions of Poland in the summers of 2004 and 2005. The first step of the proposed monitoring programme included a microscopic analysis of seasonal variation in phytoplankton composition and measurement of the cyanobacterial biomass. Then the toxigenic strains of cyanobacteria were determined by amplification of selected mcy genes in the microcystin biosynthesis pathway using PCR. The presence of the $m c y$ genes in sampling water were detected at the beginning of the July, which coincided with a low cyanobacterial biomass $(0.1 \mathrm{mg} / \mathrm{l})$. In the last step, the water samples toxicity and microcystins concentration were examined by a screening method, called protein phosphatase inhibition assay, and an analytical method, called high-performance liquid chromatography, respectively. The greatest concentration of microcystins were found to be 31.22 $\mu \mathrm{g} / 1$ (October) and $11.25 \mu \mathrm{g} / 1$ (September) in samples dominated by Planktothrix agardhii and Microcystis aeruginosa, respectively. Since a relationship between amplification of $m c y$ genes and production of microcystins was not always found, it seems to be necessary to use a microscopic analysis and molecular method in parallel with toxicity analysis for providing more complete information on the cyanobacterial risk in water.
\end{abstract}

Keywords: cyanobacteria, toxigenic strains, mcy genes, microcystin, toxicity. 


\section{Introduction}

In many countries, including Poland, the problem of toxicity caused by cyanobacterial blooms has important consequences [1-5]. Cyanobacteria and cyanotoxins are dangerous for water supply systems and recreation $[5,6]$. The most common in Polish water bodies are microcystin-producing cyanobacteria. At present, the toxins (cyanotoxins) that are produced by cyanobacteria can be classified into four main groups: hepatotoxins, neurotoxins, cytotoxins and dermatotoxins [4, 7]. Microcystins, including hepatotoxins, are the best-known group. They are synthesized nonribosomally by a peptide synthetase polyketide synthase enzyme complex encoded by the microcystin synthetase gene cluster $(m c y A-J)$, which contains $55 \mathrm{~kb}$ of DNA $[8,9]$. The microcystin biosynthesis $m c y$ genes have been used to establish molecular techniques for the detection of toxigenic cyanobacteria. Microcystins are one of the most toxic and dangerous cyanotoxins. Contact with microcystin-producing cyanobacteria in bathing water can cause skin irritations, allergic reactions and gastrointestinal symptoms $[4,10]$. Moreover, chronic exposure to low microcystins concentration in drinking water can lead to cancer promotion $[11,12]$.

According to WHO $[13,14]$ and Pilotto et al [15] the concentrations of microcystins above $2-4 \mu \mathrm{g} / \mathrm{l}$ in the samples indicated a first alert level for health risks. Irritative or allergenic effects were observed on $30 \%$ of exposed people on microcystin-producing cyanobacteria [15]. The first level of risk means a relatively low probability of adverse health effects. The second level of alert for recreational water was proposed if the concentration of microcystins is in the region of 20-50 $\mu \mathrm{g} / 1$ for the bloom consisted of Microcystis occured. However, toxic levels may approximately double if Planktothrix agardhii dominates. If the first or second level of alert appears, information to the relevant health authorities is required. Additionally, the second level of alert requites an introduction of bathing restriction and further investigation of the toxicity risk. The third alert level includes an intensive scum forming by cyanobacterial water bloom. In this case, swimming and other water-contact activities must be strictly forbidden.

The Polish regulation regarding the quality of drinking water indicates the limit of $1 \mu \mathrm{g} / \mathrm{l}$ for microcystin-LR [16]. Regulation for recreational water is addressed through a guideline that the appearance of cyanobacterial blooms should be controlled by observation of water colour, turbidity and/or odour [17]. Poland's regulations, unfortunately, do not recommend any specific standardized methods, equipments or programmes for the risk assessment resulting from Cyanobacteria exposure.

Therefore, this study is aimed at developing and evaluating a toxicity monitoring programme that would be based on the early identification of microcystin-producing genera, followed by an examination of their toxic potential and toxicity. The risk of cyanobacterial blooms was assessed in six eutrophic water bodies (105 water samples) located in different regions of Poland in the summers of 2004 and 2005. The presence and identification of toxigenic strains was studied by PCR amplification of a mcy genes. Sample 
toxicity and microcystins production were established by protein phosphatase inhibition assay (PPIA) and high-performance liquid chromatography (HPLC).

\section{Material and methods}

\subsection{Study sites}

Six water bodies from three different regions of Poland were studied: Lake Jeziorak (Northern Poland); lakes Bnińskie and Bytyńskie (Western Poland) and reservoirs Sulejów, Jeziorsko and Zegrzyn (Central Poland). The water bodies were selected because of the high intensity of recreational activities. Additionally, Zegrzyn Reservoir is a source of drinking water for Warsaw, the capital city of Poland and Sulejów Reservoirs is an alternative source of drinking water for the city of Łódź (1 million inhabitants).

\subsection{Sampling and phytoplankton analysis}

Water samples of the surface layer $(0-0.5 \mathrm{~m})$ were collected every two weeks from studied water bodies, from July to October 2004 and 2005. The chemical parameters of the monitored lakes and reservoirs were determined according to standard methods [18]. For DNA analysis, $100-200 \mathrm{ml}$ of water were filtered and filters were stored at $-20^{\circ} \mathrm{C}$ until DNA extraction. For the PPIA and HPLC analysis, water samples containing cyanobacterial material were filtered immediately on a GF/C (Whatman, England) filter and stored at $4^{\circ} \mathrm{C}$ for a maximum of $24 \mathrm{~h}$. After that, toxicity and microcystins concentration were determined.

Water samples for phytoplankton estimation were preserved in Lugol's solution and sedimented in the laboratory. Phytoplankton was counted using a Fusch-Rosenthal counting cell. The phytoplankton biomass (fresh weight) was determined based on a volumetric analysis of cells using geometric approximation. Biomass computed in volume units was transposed to freshmass (FM) assuming the specific mass of phytoplankton as a unit (=1) [19].

Concentrations of selected nutrients were assessed by spectrophotometer DR $2010 \mathrm{HACH}$.

\subsection{PCR - sample preparation and amplification}

Nucleic acid extraction from the filters was performed as described in Giovannoni et al [20]. The PCR reactions for the amplification of selected $m c y$ genes were carried out as described previously [21-23]. The part of mcyA (291297 bp) was amplified with Cd1F (5'-aaaattaaaagccgtatcaaa-3') and Cd1R (5'aaaagtgttttattagcggctcat-3') primers [21]. An 758 bp region of the $m c y B$ was amplified with FAA (5'-ctatgttatttatacatcagg-3') and RAA (5'-ctcagcttaacttgattatc-3') primers [22]. For amplification of the $m c y D$ fragment (818 bp), the primers of mcyDF (5'-gatccgattgaattagaaag-3') and mcyDR (5'gtattccccaagattgcc-3') were used [23]. An 809-812 bp region of the $m c y E$ was amplified with the mcyE-F2 (5'-gaaatttgtgtagaaggtgc-3') and mcyE-R4 
(5'-aattctaaagcccaaagacg-3') [23]. PCR products were separated by $1.5 \%$ agarose gel electrophoresis, using a constant voltage $(85 \mathrm{~V})$ and visualized using ethidium bromide.

\subsection{Estimation of microcystins toxicity}

\subsubsection{Protein phosphatase inhibition assay (PPIA)}

The inhibition of protein phosphatase type 1 (PP1) from rabbit skeletal muscle (BioLabs, New England) by microcystins was estimated according to An and Carmichael [24] with minor modification. The samples were incubated with 2.5 $\mathrm{U}$ of PP1 and $15 \mathrm{mM}$ p-nitrophenol phosphate (Fluka, UK) as a substrate was used. PPIA enables detection of microcystins at the $0.125 \mu \mathrm{g} / \mathrm{l}$ level, without concentrating the sample.

\subsubsection{High performance liquid chromatography (HPLC)}

The preparation of cyanobacterial material and determination of microcystins by HPLC-DAD was performed according to previous description [6]. Total microcystins concentration (extra and intracellular) was measured. The HPLC method enables the detection of microcystin at the $0.01 \mu \mathrm{g} / \mathrm{l}$ level after concentrating the samples.

\section{Results and discussion}

The risk of toxic cyanobacterial blooms was measured in six water bodies (lake Jeziorak and lake Bnińskie as well as the Bytyńskie, Sulejów, Jeziorsko and Zegrzyn reservoirs), which represent three different regions of Poland. These water bodies are the most intensively used for recreation in each region. Additionally, Sulejów and Zegrzyn reservoirs are a source of drinking water for the city of Łódź and Warsaw, respectively. We studied 105 of the water samples collected in summer season from July to October in 2004 and 2005.

The chemical conditions in water bodies supported the occurrence of cyanobacterial blooms. The average concentration of total phosphorus (TP) and total nitrogen (TN) almost exceeded the limits for eutrophication of reservoirs (0.1 mg P/1 and $1.5 \mathrm{mg} \mathrm{N} / 1)$ [25] (Tab.1). The low TN/TP ratio is a factor responsible for the dominance of bloom-forming cyanobacteria [26, 27].

Microscopic analysis as a first step of the proposed monitoring programme enabled description of phytoplankton composition and measurement of the cyanobacterial biomass (Tab. 1 and 2). Hepatotoxic cyanobacteria with domination by Microcystis were detected in Sulejów Reservoir, Zegrzyn Reservoir and Jeziorsko Reservoir in 2004 and 2005, also these genera were detected in Lake Jeziorak. Lakes Bnińskie and Bytyńskie were dominated by Planktothrix agardhii with the highest biomass over $50 \mathrm{mg} / \mathrm{l}$. Additionally, Cylindrospermopsis raciborskii occurred in Western lakes, in 2005. 
The inability to differentiate between toxic and nontoxic strains of cyanobacteria by morphological analysis lead to applying sensitive molecular methods, which enable identification of microcystin-producing strains [21, 28, 29]. The toxigenic strains of cyanobacteria were determined by amplification of selected $m c y$ genes $(m c y A, m c y B, m c y D$ and $m c y E)$ in the microcystin biosynthesis pathway. Genetic analysis of water samples containing cyanobacteria collected from monitored water bodies indicated that the potential to produce toxins was determined early in July and persisted throughout summer monitoring, until October 2004 and 2005 (Fig. 1). The presence of the $m c y A, B$, $D$ and $E$ genes in sampling water at the beginning of the July coincided with a low cyanobacterial biomass $(0.1 \mathrm{mg} / \mathrm{l})$ (Fig. 1 and Tab. 2). The $m c y E$ gene fragment was amplified in all water samples collected, irrespective of source or date, with the exception of the Jeziorsko reservoir. In this case, the $m c y E$ gene was amplified less often in $75 \%$ in summer season 2005 . The $m c y D$ was also amplified in all water samples but only in summer 2005. The other mcy genes were amplified less often, depending on the water body (Fig. 1). These results suggested that the $m c y A, m c y B, m c y D$ and $m c y E$ genes were different in being able to predict microcystin toxigenicity. The molecular analysis indicated that the $m c y E$ gene that encode the glutamate-activating adenylation domain is the best molecular marker for the determination of toxigenic strains of cyanobacteria in different water samples even if their biomass is very low $(0.1 \mathrm{mg} / \mathrm{l})$.

Table 1: The average concentration of nutrients and microcystin- producing cyanobacteria in studied water bodies in the summers of 2004 and 2005.

\begin{tabular}{|c|c|c|c|c|c|}
\hline Water body & Year & $\mathrm{TN}$ & $\mathrm{TP}$ & $* \mathrm{TN} / \mathrm{TP}$ & Cyanobacteria \\
\hline \multirow[t]{2}{*}{ Sulejów } & 2004 & 1.00 & 0.14 & 9.70 & Microcystis aeruginosa \\
\hline & 2005 & 1.18 & 0.10 & 10.85 & Microcystis aeruginosa \\
\hline \multirow[t]{2}{*}{ Jeziorsko } & 2004 & 1.20 & 0.10 & 11.60 & Microcystis aeruginosa \\
\hline & 2005 & 2.84 & 0.59 & 9.48 & Microcystis aeruginosa \\
\hline \multirow[t]{2}{*}{ Zegrzyn } & 2004 & 1.40 & 0.20 & 8.50 & $\begin{array}{c}\text { Microcystis aeruginosa } \\
\text { Microcystis viridis }\end{array}$ \\
\hline & 2005 & 1.02 & 0.21 & 6.18 & Microcystis aeruginosa \\
\hline \multirow[t]{2}{*}{ Bnińskie } & 2004 & 2.30 & 0.21 & 12.40 & Planktothrix agardhii, \\
\hline & 2005 & 2.21 & 0.10 & 16.06 & $\begin{array}{c}\text { Planktothrix agardhii, } \\
\text { Cylindrospermopsis } \\
\text { raciborskii }\end{array}$ \\
\hline \multirow[t]{2}{*}{ Bytyńskie } & 2004 & 0.80 & 0.11 & 10.10 & Planktothrix agardhii \\
\hline & 2005 & 1.84 & 0.12 & 18.5 & Planktothrix agardhii \\
\hline \multirow[t]{2}{*}{ Jeziorak } & 2004 & 1.50 & 0.08 & 20.90 & Microcystis aeruginosa \\
\hline & 2005 & 1.46 & 0.11 & 12.63 & Microcystis aeruginosa \\
\hline
\end{tabular}

* - TN/TP - the ratio between total nitrogen (TN) and total phosphorus (TP). 


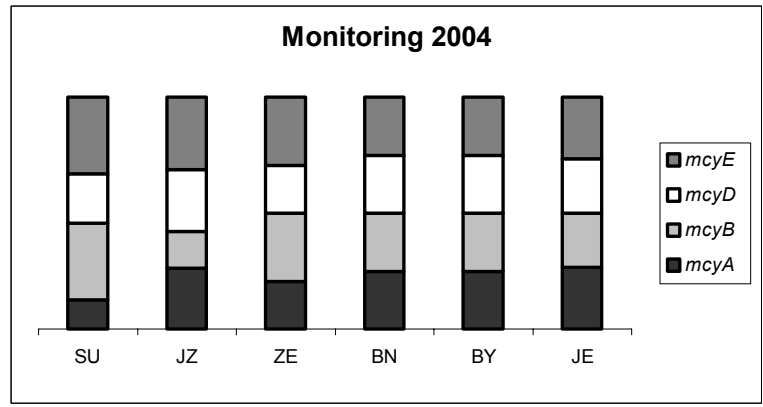

A.

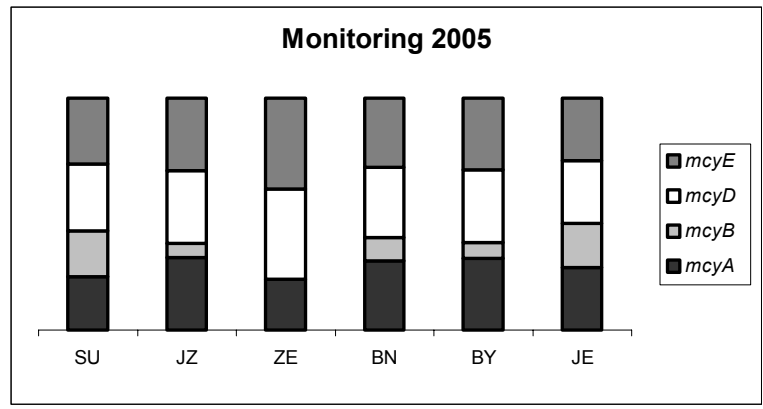

B.

Figure 1: $\quad$ PCR results of $m c y$ genes amplification in summer A) 2004 and B) 2005 .

However, although genetic markers provided information about potential toxicity they did not indicate what the real risk to health was. Therefore, toxicological analysis of water as the last step of the proposed monitoring programme was needed. Microcystins production and their toxicity was measured by biochemical (PPIA) and analytical (HPLC) methods. The presented data indicated variations in microcystin concentrations in water samples collected from different water bodies (Tab. 1). Additionally, seasonal variations were observed also. Samples collected in 2004 were more toxic than samples from 2005. The greatest concentration of microcystins were found to be 31.22 $\mu \mathrm{g} / \mathrm{l}$ (Lake Bnińskie, October 2004) and $11.25 \mu \mathrm{g} / \mathrm{l}$ (Jeziorsko reservoir, September 2004) in samples dominated by Planktothrix agardhii and Microcystis aeruginosa, respectively (Tab. 1 and 2). In Sulejów reservoir the highest microcystins concentration $(4.67 \mu \mathrm{g} / \mathrm{l})$ was found in September 2004. The low microcystins concentration with a maximum of $0.63 \mu \mathrm{g} / \mathrm{l}$ was detected in Lake Jeziorak. These variations detected in the water body might be a result of population dynamics altering the proportion of toxic genotypes within the population of cyanobacteria [30]. Additionally, physicochemical conditions that 
were not studied could be an influence on the dynamics of cyanobacteria growth and their toxigenicity (microcystins production). Microcystins were almost not detected in the Zegrzyn reservoir in spite of $m c y$ genes amplification. Non-toxic strains do not generally contain the $m c y$ genes. However, some strains may have fragments of microcystin synthetase genes or mutations within these genes. Therefore, these strains can be amplified with $m c y$ primers, although they are not able to produce toxins [29]. Nishizawa et al [31] suggested that non-toxic Microcystis strains comprise two groups: those with and those without $m c y A B C$.

Table 2: The maximum of the microcystins concentration and biomass of hepatotoxic cyanobacteria in the summers of 2004 and 2005.

\begin{tabular}{cccccccccc}
\hline & & \multicolumn{3}{c}{ July } & \multicolumn{2}{c}{ August } & \multicolumn{2}{c}{ September } & \multicolumn{2}{c}{ October } \\
\cline { 3 - 10 } Water body & & 2004 & 2005 & 2004 & 2005 & 2004 & 2005 & 2004 & 2005 \\
\hline Sulejów & *Biomass & 0.12 & 43.64 & 0.87 & 29.58 & 9.70 & 8.12 & 1.30 & 2.31 \\
& PPIA & 3.96 & 2.83 & 3.48 & 2.27 & $>4.00$ & 0.76 & 0.94 & 1.09 \\
& $* *$ HPLC & & & & & 4.67 & & & \\
Jeziorsko & $*$ Biomass & 0.90 & 0.97 & 52.55 & 0.76 & 27.3 & 34.22 & 0.61 & 0.93 \\
& PPIA & 0.36 & 0.72 & 3.67 & 0.85 & $>4.00$ & 1.55 & 0.41 & 0.56 \\
& $* *$ HPLC & & & & & 11.25 & & & \\
Zegrzyn & $*$ Biomass & 0.11 & 0.57 & 3.62 & 0.41 & 1.33 & 0.62 & 2.23 & 0.12 \\
& PPIA & $<0.13$ & 0.32 & $<0.13$ & $<0.13$ & $<0.13$ & $<0.13$ & 0.42 & $<0.13$ \\
& $* *$ HPLC & n.d. & & n.d. & n.d. & n.d. & 0.05 & & n.d. \\
Bnińskie & $*$ Biomass & 50.50 & 0.03 & 32.75 & 0.06 & 51.13 & 1.99 & 33.71 & 3.66 \\
& PPIA & $>4.00$ & 0.66 & $>4.00$ & 0.56 & $>4.00$ & 0.82 & $>4.00$ & 2.19 \\
& $* *$ HPLC & 10.98 & & 10.67 & & 11.13 & & 6.98 & \\
Bytyńskie & $*$ Biomass & 31.5 & 0.18 & 40.18 & 0.453 & 44.55 & 1.08 & 53.54 & 1.813 \\
& PPIA & $>4.00$ & 0.60 & $>4.00$ & 0.48 & $>4.00$ & 0.63 & $>4.00$ & 0.59 \\
& $* *$ HPLC & 12,61 & & 16.06 & & 31.22 & & 18.62 & \\
Jeziorak & $*$ Biomass & 1.20 & 5.9 & 2.30 & 3.39 & 0.10 & 1.04 & 4.10 & 3.78 \\
& PPIA & 0.34 & 0.50 & 0.31 & 0.52 & 0.47 & 0.17 & 0.23 & 0.63 \\
& $* *$ HPLC & & & & & & & & \\
\hline
\end{tabular}

* - biomass of hepatotoxic cyanobacteria [mg/l] in samples with maximum microcystins concentration.

** - if microcystins concentration was below $0.13 \mu \mathrm{g} / \mathrm{l}$ or exceeded $4 \mu \mathrm{g} / \mathrm{l}$, the high performance liquid chromatography (HPLC) technique was used.

The highest microcystins concentration ( $>20 \mu \mathrm{g} / \mathrm{l})$ corresponds to the second alert level for recreational water as determined for the lakes of Western Poland. In Central Poland the concentration of microcystins reached the first alert level $(>2 \mu \mathrm{g} / \mathrm{l})$. In the lake in Northern Poland the occurrence of microcystin did not exceed $1 \mu \mathrm{g} / \mathrm{l}$ in the whole sampling period. 
In conclusion, the microscopic analysis of water samples from six Polish water bodies indicated an appearance of microcystin-producing cyanobacteria. The most common was Microcystis and Planktothrix genera. The microscopic detection of cyanobacteria and determination of toxigenic strains by molecular markers ( $m c y$ genes) was an early signal of potential toxicity of cyanobacterial blooms, and acts as an effective alert to possible health risk. However, only biochemical and analytical methods enabled determination of microcystins concentration in studied water bodies. Therefore, it seems to be necessary to use a microscopic analysis and molecular method in parallel with toxicity analysis for providing complete information on the cyanobacterial risk in water.

\section{Acknowledgments}

These studies were supported by State Committee for Scientific Research 2PO4F 04427.

\section{References}

[1] Fleming, L.E., Rivero, C., Burns, J., Williams, Ch., Bean, J.A., Shea, K.A. \& Stinn, J., Blue green algal (cyanobacterial) toxins, surface drinking water, and liver cancer in Florida. Harmful Algae, 1, pp. 157-168, 2002.

[2] De Figueiredo, D.R., Azeiteiro, U.M., Esteves, S.M., Goncalves, F.J.M. \& Pereira, M.J., Microcystin-producing blooms - a serious global public health issue. Ecotoxicology and Environmental Safety, 59, pp. 151-163, 2004.

[3] Pawlik-Skowrońska, B., Skowroński, T., Pirszel, J. \& Adamczyk A., Relationship between cyanobacterial bloom composition and anatoxin-a and microcystin occurrence in the eutrophic dam reservoir (SE Poland). Polish Journal of Ecology, 52, pp. 479-490, 2004.

[4] Mankiewicz, J., Tarczyńska, M., Walter, Z. \& Zalewski, M., Natural Toxins from Cyanobacteria (Blue-Green Algae). Acta Biologica Cracoviensia, 45(2), pp. 9-20, 2003.

[5] Mankiewicz, J., Komarkova, J., Izydorczyk, K., Jurczak, T., † Tarczyńska, M. \& Zalewski M., Hepatotoxic cyanobacterial blooms in lakes of North Poland. Environmental Toxicology, 20, pp. 499-506, 2005.

[6] Jurczak, T., Tarczyńska, M., Izydorczyk, K., Mankiewicz, J., Zalewski, M. \& Meriluoto J., Elimination of microcystins by water treatment process - examples from Sulejow Reservoir, Poland. Water Research, 39, pp. 2394-2406, 2005.

[7] Codd, G.A., Morrison, L.F. \& Metcalf, J.S., Cyanobacterial toxins: risk management for health protection. Toxicology and Applied Pharmacology, 203, pp. 264-272, 2005.

[8] Tillett, D., Dittmann, E., Erhard, M., von Döhren, Börner, T. \& Neilan, B.A., Structural organization of microcystin biosynthesis in Microcystis aeruginosa PCC7806 : an integrated peptide-polyketide synthetase system. Chemistry \& Biology, 7, pp. 753-764, 2000. 
[9] Christiansen, G., Fastner, J., Erhard, M., Borner, T. \& Dittman E., Microcystin Biosynthesis in Planktothrix: Genes, Evolution and Manipulation. Journal of Bacteriology, 185, pp. 564-572, 2003.

[10] Chorus, I. \& Bartram J., Toxic Cyanobacteria in Water. A Guide to their Public Health Consequences, Monitoring and management, E.\&F. N. Spon: London, 1999.

[11] Carmichael, W.W., Heath Effects of Toxin-Producing cyanobacteria: The CyanoHABs. HERA, 7, pp. 1393-1407, 2001.

[12] Briand, J.F., Jacquet, S., Bernard, C. \& Humbert, J.F., Health hazards for terrestrial vertebrates from toxic cyanobacteria in surface water ecosystems. Veterinary Research, 34, pp. 361-377, 2003.

[13] Falconer, I.R., An overview of problems caused by toxic Blue-Green Algae (Cyanobacteria) in drinking and recreational water. Environmental Toxicology and Water Quality, 14, pp. 5-12, 1999.

[14] WHO, Guidelines for safe recreational water environments. Coastal and fresh waters, 1, pp.150, 2003.

[15] Pilotto, L.S., Burch, M.D., Douglas, R.M., Cameron, S., Roach, G.J., Cowie, C.T., Beers. M., Robinson, P., Kirk, M., Hardman, S., Moore, C. $\&$ Attewell, R.G., Health effect of exposure to cyanobacteria (blue-green algae) during recreational water activities. Australian and New Zealand Journal of Public Health, 21, pp. 562-566, 1997.

[16] Ministry of Health regulation, Regulation of the Minister of Health of $19 / 11 / 02$ on the requirements concerning the quality of drinking water. Journal of Laws № 203/2002, item 1718, 2002a.

[17] Ministry of Health regulation, Regulation of the Minister of Health of $16 / 10 / 02$ on the requirements concerning the quality of bathing water. Journal of Laws № 183/2002, item 1530, 2002b.

[18] Golterman, H.L., Clynio, R.S. \& Ohstand M.A.M., Methods for physical and chemical analysis of freshwater, IBP Hand Book, 1988.

[19] Komárkowá, J., Vyhnalek, V. \& Kubecka J., Impact of fishstock manipulation on the composition of net phytoplankton in the Rimov Reservoir (Czech Republic). Water Science and Technology, 32, pp. 207-216, 1995.

[20] Giovannoni, S.J., DeLong, E.F., Schmidt, T.M. \& Pace N.R., Tangential flow filtration and preliminary phylogenetic analysis of marine picoplankton. Applied and Environmental Microbiology, 568, pp. $2572-2575,1990$.

[21] Hisbergues, M., Christiansen, G., Rouhiainen, L., Sivonen, K. \& Borner T., PCR-based identification of microcysin-producing genotypes of different cyanobacterial genera. Archives of Microbiology, 180, pp. 402-410, 2003.

[22] Bittencourt-Oliveira, M., Detection of potential microcystin-producing cyanobacteria in Brazilian reservoirs with a $m c y B$ molecular marker. Harmful Algae, 2, pp. 51-60, 2003. 
[23] Rantala, A., Fewer, D.P., Hisbergues, M., Rouhiainen, L., Vaitomaa, J., Börner, T. \& Sivonen, K., Phylogenetic evidence for the early evolution of microcystin synthesis. PNAS, 101(2), pp. 568-573, 2004.

[24] An, J.S. \& Carmichael, W.W., Use a colorymetric protein phosphatase inhibition assay and enzyme linked immunosorbent assay for study of microcystins and nodularins. Toxicon, 32, pp. 1495-1507, 1994.

[25] OECD, Eutrophication of water. Monitoring assessment and control. Technical Report. Environment Directorate, OECD, Paris, pp. 154, 1983.

[26] Rapala, J., Sivonen, K., Lyra, C. \& Niemela, S. I., Variation of Microcystin, Cyanobacterial hepatotoxins, in Anabaena spp. as a function of growth stimulate. Applied and Environmental Microbiology, 63, pp. 2206-2212, 1997.

[27] Kaebernick, M. \& Neilan, B.A., Ecological and molecular investigations of cyanotoxin production. FEMS Microbiology Letters, 35, pp. 1-9, 2001.

[28] Kurmayer, R., Dittmann, E., Fastner, J. \& Chorus, I., Diversity of microcystin genes within a population of the toxic cyanobacterium Microcystis spp. in Lake Wannsee (Berlin, Germany). Microbiol Ecology, 43, pp.107-118, 2002.

[29] Vaitomaa, J., Rantala, A., Halinen, K., Rouhiainen, L., Tallberg, P., Mokelke, L. \& Sivonen K., Quantitative Real-Time PCR for Determination of Microcystin Synthetse E Copy Numbers for Microcystis and Anabaena in Lakes. Applied and Environmental Microbiology, 69, pp. 7289-7297, 2003.

[30] Dittmann, E. \& Börner, T., Genetic contributions to the risk assessment of microcystin in the environment. Toxicology and Applied Pharmacology, 203, pp. 192-200, 2005.

[31] Nishizawa, T., Ueda, A., Asayama, M., Fujii, K., Harada, K., Ochi, K. \& Shirai, M., Polyketide Synthase Gene Coupled to the Peptide Synthetase Module Involved in the Biosynthesis of the Cyclic Heptapeptide Microcystin. Journal of Biochemistry, 127, pp. 779-789, 2000. 